\section{The Gold Standard}

Compared with that of other metals the production of gold is insignificant, and recent events which have demonstrated the defects in the gold standard and induced many nations to come off the gold standard have led many people to wonder whether gold is a suitable metal to be used as a standard at all. The diagrams and models prepared by Sir Robert Hadfield enable us to visualise more clearly the extent to which gold can now be merely a basis for currency. On the other hand, while the output of gold according to expert opinion shows a marked tendency to decrease, the increasing volume of the world's trade tends to augment the demand for gold as a basis for currency under our old systems of currency. In addition, the concentration of 75 per cent of the gold stocks of the world in the United States of America and France, where it is not used as the basis of so much money as in the countries from which it was withdrawn, has tended to accentuate the shortage. Without advocating a definite change or the adoption of bimetallism, Sir Robert suggested that the currency situation merited expert investigation and consideration by an authoritative international organisation such as the League of Nations. Certain reforms have in fact already been suggested by the League of Nations' Gold Delegation, and are outlined in a recent memorandum on "The Functioning of the Gold Standard ", submitted by Dr. Feliks Mlynarski, which equally with Sir Robert Hadfield's speech will repay study not only by economists but also by those who are endeavouring to arrive at an intelligent view of the world's financial and economic situation.

\section{Return of the William Scoresby}

THE Royal Research Ship William Scoresby reached London on June 6 after a commission of nineteen months in the service of the "Discovery Committee". On her arrival at the East India Docks she was inspected by Mr. E. R. Darnley, chairman of the committee, and by Vice-Admiral H. P. Douglas, who congratulated her personnel on the valuable scientific results which had been obtained. The work of the ship has been in the charge of Mr. E. R. Gunther as chief scientific officer, with Commander T. A. Jolliffe, R.N. (retd.), in executive command. After leaving England in November 1930, the William Scoresby was engaged for some months in oceanographic work on the whaling areas of the dependencies of the Falkland Islands, during which, with favourable ice conditions, observations were extended so far south as lat. $70^{\circ}$. During the southern winter of 1931 she was occupied in a survey of the Humboldt current on the west coast of South America, taking fifteen lines of stations at right angles to the coast, at each of which observations were made on the plankton and on the physical characteristics of the water at different depths. The lines of stations cover an area extending from Cape Carranza to Santa Elena, a distance of about 2200 miles, and it is already clear that the results will provide much new information on the current and on the wealth of animal life that it contains. More recently the ship has been employed in a third and final survey of the trawling grounds lying between the Falkland Islands and the American coast. The survey was carried out with great thoroughness, and is expected to yield adequate data on the commercial possibilities of the area.

\section{Mexican Earthquake of June 3}

As earthquake of unusual severity occurred early on June 3 in the west of Mexico. The towns most seriously damaged, as known at the time of writing, are Colima and Guadalajara, which lie between 270 and 290 miles to the west of Mexico City. At Colima seventeen persons were killed, and at Guadalajara and in the surrounding district more than thirty. In the whole area, the number of lives lost is estimated at more than four hundred. Manzanillo, about twentyfive miles west of Colima and on the sea coast, is believed to have suffered more severely than either of the above cities, but all communications with it have been interrupted. In Mexico City, three violent shocks were felt, though the damage there was slight. According to the Mexican Seismological Bureau, the epicentre was 400 miles from the capital, and thus, as it lay in the direction of Colima and Manzanillo, it must be submarine, as in so many other recent Mexican earthquakes, but somewhat farther to the west. As in other earthquakes of the same country, the area of damage was of great extent, suggesting that the depth of the focus was considerable.

\section{Challenge to Witches in West Africa}

THE sequel to the challenge to witches issued by the Christian Council of the Missions of West Africa (see NAture, March 26, p. 464) was described by the Bishop of Accra at the fifth festival of the Accra Diocesan Association, held at Westminster on May 31. He recalled that the Council, in its desire to show that a great deal of West African witcheraft is nothing but fraud, had offered the sum of $£ 10$ to any witch who, in the presence of a representative of the council, should perform one of their favourite tricks, such as eat a papaw from a distance, remove an article from a locked box, or change a person into a bird, beast, or fish. Up to the time he left Accra some weeks ago, the only reply to the challenge had come from a wizard, who was unable to come to Accra, but offered, if the Council would go to him, to kill a man at a distance of forty miles. The Bishop hoped the challenge would be taken up, though not exactly in that form. The witches of Africa, he said, form a great secret society which is a source of harm to the people. The Europeans are outside a wall drawn around the native, as it were, and know very little about what goes on within.

\section{Guthrie Lecture of the Physical Society}

THE seventeenth Guthrie Lecture to the Physical Society will be delivered on June 17 at 5 P.M. at the Imperial College of Science and Technology, South Kensington, by Dr. Max Planck, of Berlin, who will take as his subject "The Concept of Causality in Physics ". Planck's greatest scientific achievements are the outcome of a study of thermodynamical principles and their multifarious applications. $\mathrm{He}$ was

No. 3267, VoL. 129] 
thus led at the end of last century to the problems presented by full radiation, the last remaining prob. lem of which, that of the energy distribution, he solved by formulating the quantum theory. The new feature in Planck's theory finds its expression in terms of the 'quantum of action', symbolised by the letter $h$ (Planck's constant). This is a very small quantity, and the quantum theory consequently exhibits its special peculiarities only when applied to the smallscale phenomena for which it is needed. Applied to large-scale phenomena it coalesces, as it should do, with classical physical theory (in which we may include relativity). Planck's work has been ereative in a higher sense than that of any of his contemporaries or predecessors, in that it has introduced, for the first time in the history of science, concepts that are really new.

\section{Grasshopper Invasion in the United States}

Ww learn from Science Service, of Washington, D.C. (May 12), that a grasshopper invasion of exceptional severity is predicted to occur over the western United States. Field observations carried out over many years have shown that dry summers followed by relatively mild winters provide ideal conditions for these insects. The summer of 1930 was the dryest on record, while that of 1931 was one of the hottest, as well as being a dry one. The past two winters have not been severe, and the consequence is that grasshoppers have become increasingly numerous in parts of the west. Last year, vast number of eggs were deposited in the ground, and now these eggs are hatching. The only possible control measure consists in the broadcasting of an arsenic-poisoned bran-mash bait, which the insects devour with avidity, and are killed thereby. The cost of its application over wide areas is large, and strong endeavours are being made to obtain funds from Congress that will enable the western farmer to apply this weapon in time to save his crops. Ample warning appears to have been given by entomologists, and others, with respect to what is described as the greatest grasshopper invasion of the past half-century, that is now threatening a large section of the country. It is obvious that only coordinated and very prompt action can alleviate the situation that is predicted to arise.

\section{Celery Growing}

Is view of the increase in consumption and production of celery in Great Britain, the Ministry of Agriculture has recently issued a new bulletin (No. 47) on celery growing (London: H.M. Stationery Office. $6 d$.$) , in which the cultural methods used by the$ specialist growers and the results of scientific investigations obtained by the Midland Agricultural College are described. At one time the chief celerygrowing district was the Isle of Axholme, but it is now produced to a considerable extent in Lancashire, the Fens of Cambridgeshire, and Huntingdonshire. A good celery soil must be deep, though easily worked, and contain a high percentage of organic matter. The water supply must be plentiful, but good drainage is essential. Besides a heavy application of farmyard manure, a dressing of superphosphate is recom- mended prior to planting, while a top dressing of sulphate of ammonia is commonly given in July. The plants are raised from seed in hotbeds, and after being bedded out in small plots for about two months, are transferred to the field about June, this final planting being a highly skilled operation. The time at which the celery is lifted depends on the variety and nature of the soil, but it may be ready as early as the end of August. The question of the best methods of grading and trimming for the market is receiving attention. The avoidance of disease is of the utmost importance in celery growing. If entirely clean seed is not procurable, it should be treated with some disinfectant, such as weak formalin, before being sown, and further, spraying of the plants both in the beds and in the fields should be regarded as a routine operation if a successful crop is to be obtained. For further particulars of such treatments, readers are referred to Bulletin 25, where celery diseases and their control are dealt with in detail.

\section{Early Man in Java}

Details of the discovery of another new type of man in Java a few months ago have now been published, as is noted by Prof. Elliot Smith in a letter to the Times of June 3. The discovery was made by $\mathrm{Mr}$. C. Ter Haar, and the remains and circumstances of discovery are described by Mr. F. F. Oppenoorth, of the Geological Survey of Java, in the official publica. tion of the Survey, issued at Batavia. In the course of the examination of the pilocene and pleistocene deposits of the Solo River valley, the greater part of a brain-case and two fragments of a second were found in a bone bed at Ngandong, more than twenty miles from Trinil, where Dr. Dubois found the remains of Pithecanthropus erectus in 189J. The fossil bones of fauna associated with the Ngandong find point to a mid-pleistocene age. The brain-case is described as of a more advanced type than Pithecanthropus, and to resemble more nearly Neanderthal man and the Rhodesian skull. It is, however, definitely more primitive than either and probably more ancient. The name suggested for this new species of the buman family is Homo soloensis.

\section{Criminal Anthropology}

Criminal anthropology, which for some time has suffered an eclipse owing to ill-judged claims which had little or no foundation on sound observation, is once more attracting the attention of investigators. In Scientia for May, Prof. A. Mendes-Corrêa re. capitulates views which he has put forward from time to time on the contribution which a re-orientated anthropological method can make to the study of criminals and to practical measures in dealing with delinquents. The method advocated by the author is based on a study of the individual, whether normal or abnormal, in reference to his individual psychic and moral make-up and his biological and sociological conditions. Measurements, somatic characters, mental tests, and other methods employed in dealing with delinquents and defectives are regarded as auxiliary rather than as primary methods of investigation in criminological research. Prof. Mendes-Corrêa rega

No. 3267, Vou. 129] 